NASA/TM-2004-213356

\title{
Control of a High Speed Flywheel System for Energy Storage in Space Applications
}

Barbara H. Kenny

Glenn Research Center, Cleveland, Ohio

Peter E. Kascak and Ralph Jansen

University of Toledo, Toledo, Ohio

Timothy Dever

QSS Group, Inc., Cleveland, Ohio

Walter Santiago

Glenn Research Center, Cleveland, Ohio 
Since its founding, NASA has been dedicated to the advancement of aeronautics and space science. The NASA Scientific and Technical Information (STI) Program Office plays a key part in helping NASA maintain this important role.

The NASA STI Program Office is operated by Langley Research Center, the Lead Center for NASA's scientific and technical information. The NASA STI Program Office provides access to the NASA STI Database, the largest collection of aeronautical and space science STI in the world. The Program Office is also NASA's institutional mechanism for disseminating the results of its research and development activities. These results are published by NASA in the NASA STI Report Series, which includes the following report types:

- TECHNICAL PUBLICATION. Reports of completed research or a major significant phase of research that present the results of NASA programs and include extensive data or theoretical analysis. Includes compilations of significant scientific and technical data and information deemed to be of continuing reference value. NASA's counterpart of peerreviewed formal professional papers but has less stringent limitations on manuscript length and extent of graphic presentations.

- TECHNICAL MEMORANDUM. Scientific and technical findings that are preliminary or of specialized interest, e.g., quick release reports, working papers, and bibliographies that contain minimal annotation. Does not contain extensive analysis.

- CONTRACTOR REPORT. Scientific and technical findings by NASA-sponsored contractors and grantees.
- CONFERENCE PUBLICATION. Collected papers from scientific and technical conferences, symposia, seminars, or other meetings sponsored or cosponsored by NASA.

- SPECIAL PUBLICATION. Scientific, technical, or historical information from NASA programs, projects, and missions, often concerned with subjects having substantial public interest.

- TECHNICAL TRANSLATION. Englishlanguage translations of foreign scientific and technical material pertinent to NASA's mission.

Specialized services that complement the STI Program Office's diverse offerings include creating custom thesauri, building customized databases, organizing and publishing research results ... even providing videos.

For more information about the NASA STI Program Office, see the following:

- Access the NASA STI Program Home Page at http://www.sti.nasa.gov

- E-mail your question via the Internet to help@sti.nasa.gov

- Fax your question to the NASA Access Help Desk at 301-621-0134

- Telephone the NASA Access Help Desk at 301-621-0390

- Write to:

NASA Access Help Desk

NASA Center for AeroSpace Information 7121 Standard Drive

Hanover, MD 21076 
NASA/TM-2004-213356

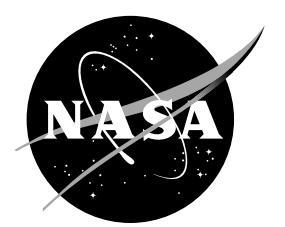

\section{Control of a High Speed Flywheel System for Energy Storage in Space Applications}

Barbara H. Kenny

Glenn Research Center, Cleveland, Ohio

Peter E. Kascak and Ralph Jansen

University of Toledo, Toledo, Ohio

Timothy Dever

QSS Group, Inc., Cleveland, Ohio

Walter Santiago

Glenn Research Center, Cleveland, Ohio

National Aeronautics and

Space Administration

Glenn Research Center 
Trade names or manufacturers' names are used in this report for identification only. This usage does not constitute an official endorsement, either expressed or implied, by the National Aeronautics and Space Administration.

Available from

NASA Center for Aerospace Information 7121 Standard Drive

Hanover, MD 21076
National Technical Information Service 5285 Port Royal Road Springfield, VA 22100

Available electronically at http:/ /gltrs.grc.nasa.gov 


\section{Control of a High Speed Flywheel System for Energy Storage in Space Applications}

\author{
Barbara H. Kenny \\ National Aeronautics and \\ Space Administration \\ Glenn Research Center \\ Cleveland, Ohio 44135
}

\author{
Peter E. Kascak and Ralph Jansen \\ University of Toledo \\ Toledo, Ohio 43606
}

\author{
Timothy Dever \\ QSS Group, Inc. \\ Cleveland, Ohio 44135
}

\author{
Walter Santiago \\ National Aeronautics and \\ Space Administration \\ Glenn Research Center \\ Cleveland, Ohio 44135
}

\begin{abstract}
A novel control algorithm for the charge and discharge modes of operation of a flywheel energy storage system for space applications is presented. The motor control portion of the algorithm uses sensorless field oriented control with position and speed estimates determined from a signal injection technique at low speeds and a back EMF technique at higher speeds. The charge and discharge portion of the algorithm use command feed-forward and disturbance decoupling, respectively, to achieve fast response with low gains. Simulation and experimental results are presented demonstrating the successful operation of the flywheel control up to the rated speed of $60,000 \mathrm{rpm}$.
\end{abstract}

\section{INTRODUCTION}

Energy storage on the Space Station and satellites is currently accomplished using chemical batteries, most commonly nickel hydrogen or nickel cadmium. A flywheel energy storage system is an alternative technology that is being considered for future space missions. Flywheels offer the advantage of a longer lifetime, higher efficiency and a greater depth of discharge than batteries. However, several advanced technologies must be demonstrated for the flywheel energy storage system to be a viable option for future space missions. These include high strength composite materials, highly efficient high speed motor operation and control, and magnetic bearing levitation. To demonstrate the successful combination of these technologies, a flywheel energy storage system testbed has been constructed at the NASA Glenn Research Center.

Figure 1 shows the main components of the flywheel energy storage system. They are the composite rotor, motor/generator, magnetic bearings, touchdown bearings, and vacuum housing (needed in the testbed but not necessary for a flywheel operating in space). The flywheel system is designed for 364 watt-hours of energy storage at $60,000 \mathrm{rpm}$ with a 9" diameter rim and a maximum tip speed of 700 $\mathrm{m} / \mathrm{sec}$.

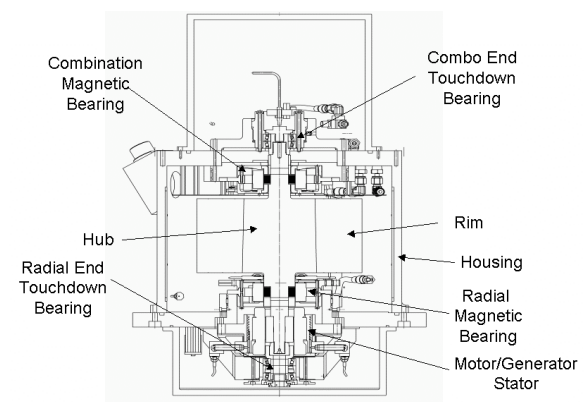

Figure 1: Flywheel energy storage system.
Active magnetic bearings provide a long-life, low-loss suspension of the rotating mass. The upper bearing of the unit is a combination magnetic bearing, providing suspension axially as well as radially. The lower magnetic bearing suspends the shaft in the radial direction only. At each end of the shaft there is also a touchdown bearing. This provides a back up bearing system should the magnetic bearings fail during testing.

The motor/generator unit is located at the lower end of the shaft. It consists of a two-pole rotor piece with surface mounted samarium cobalt magnets and a carbon fiber retaining wrap. On the stator side, there are three phase sinusoidally distributed windings in twelve slots. A water jacket around the stator provides cooling. Field orientation and a combination of mechanical sensorless techniques are used to control the motor from zero and low speed up to full speed operation [1]. The self-sensing technique [2] is used at zero and low speeds to start the machine, then the control is switched to a back-EMF based sensorless technique [3] for the normal higher speed operating range of the machine. This combined technique was previously demonstrated in [4] however the machine used in that case was an interior PM machine for an electric vehicle application.

The torque command to the field orientation algorithm is provided by an outer loop control algorithm that regulates the flywheel motor during both charge (motoring) and discharge (generating) operation [5,6]. During charge mode, the flywheel can be charged at a constant power rate with the appropriate torque command while during discharge, the flywheel provides the power necessary to regulate the DC bus voltage to a set value and supply the loads.

The contribution of this paper is the derivation, simulation and high speed experimental verification of the flywheel system control algorithm.

\section{Motor/GenerATOR AND CONTROL}

The rated power of the two pole surface mount PM machine is $1.5 \mathrm{~kW}$ and the rated phase voltage is 65 volts peak. At full speed, $60,000 \mathrm{rpm}$, the fundamental frequency is $1 \mathrm{kHz}$.

The block diagram of the controller is shown in Fig. 2. As stated previously, the inner loop torque control of the motor is based on the field orientation algorithm using one of two sensorless position estimates. The rotor reference frame qaxis current command is provided by the charge/discharge controller that is described in Section III. 


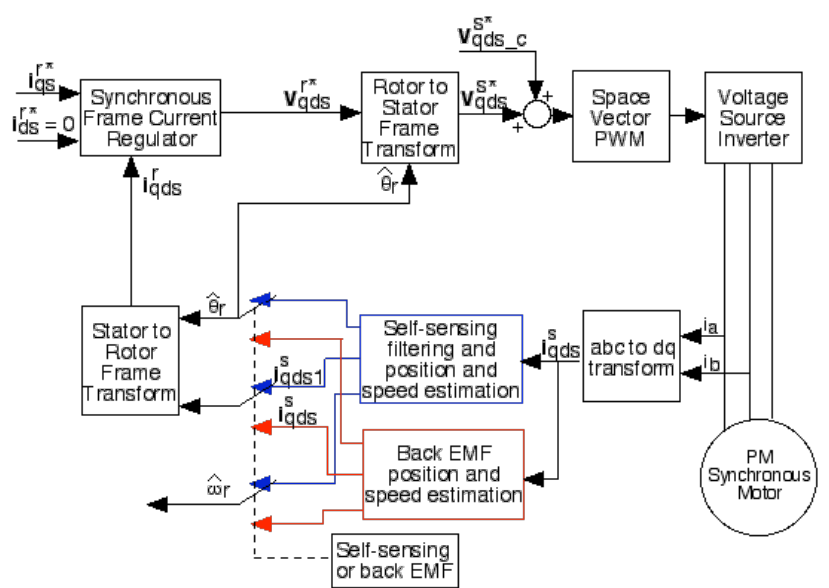

Figure 2: Block diagram of flywheel motor control.

The control algorithm starts the motor using an initiation algorithm to set the rotor to a known position as described in [7]. Then the self-sensing algorithm [2] is used to accelerate the motor from standstill to $1200 \mathrm{rpm}$. The self-sensing technique requires a position dependent magnetic saliency in the machine. The flywheel motor has a small saliency as can be seen in the static phase to phase inductance measurement as a function of position shown in Fig. 3.

At $1200 \mathrm{rpm}$, the position and speed estimates are determined from the back-EMF method [3]. The carrier signal voltage necessary for the self-sensing method, $\mathbf{V}_{\mathrm{qds}}^{\text {s* }}$, is then removed. The estimated position from each of the methods is shown at this transition point in Fig. 4. The transition occurs at time $\mathrm{t}=0$ with the system operating using the self-sensing technique for $t<0$ and with the back EMF technique for $\mathrm{t}>0$. Both methods are producing reliable position and speed estimates at this point and there is a seamless transition between them. However, the machine does not have a resolver or encoder so the absolute accuracy of the position estimates can not be explicitly verified.

For the purposes of describing the overall control algorithm, it is sufficient to describe in more detail only the back-EMF estimation technique because the operation of interest is at the higher speeds. Further information on the combined technique can be found in $[1,4]$.

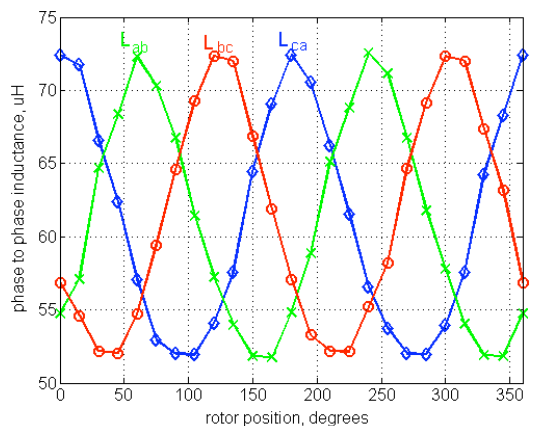

Figure 3: Measured phase to phase inductance variation with rotor position.

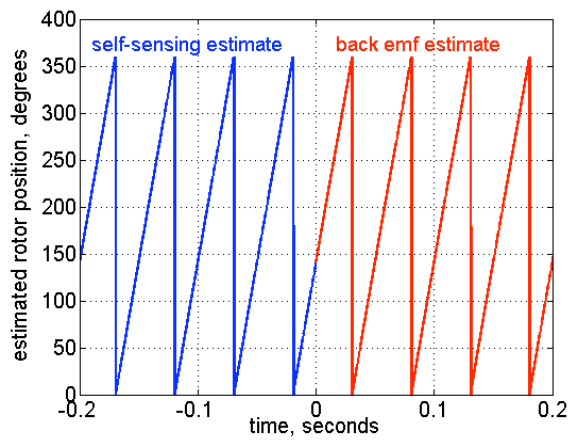

Figure 4: Estimated rotor position during self-sensing to back emf transition

A.

\section{Back-EMF estimation technique}

The stator reference frame equation describing the relationship between the stator voltage, current and flux linkages for the fundamental excitation of the machine is given in (1).

$$
\mathbf{v}_{\mathrm{qds}}^{\mathrm{s}}=\mathbf{i}_{\mathrm{qds}}^{\mathrm{s}} R_{\mathrm{s}}+p \square_{\mathrm{qds}}^{\mathrm{s}}
$$

The stator flux can be estimated by integrating the stator voltage less the IR drop as shown in (2).

$$
\mathbf{Q}_{\mathrm{qds}}^{\mathrm{s}}=\text { 目目 } \mathbf{v}_{\mathrm{qds}}^{\mathrm{s}}-\mathbf{i}_{\mathrm{qds}}^{\mathrm{s}} \mathrm{R}_{\mathrm{s}} \mathrm{Bdt}_{\mathrm{dt}}
$$

In the actual implementation, a low pass filter is used instead of pure integration to avoid low frequency integration problems. The torque angle, $\square$, can be found by expressing the stator flux in the rotor reference frame as shown in (3), (4) and (5).

$$
\begin{aligned}
& \square_{\mathrm{qs}}^{\mathrm{r}}=\mathrm{L}_{\mathrm{q}} \mathrm{i}_{\mathrm{qs}}^{\mathrm{r}} \\
& \square_{d s}^{r}=L_{d} i_{d s}^{r}+\square_{a f}
\end{aligned}
$$

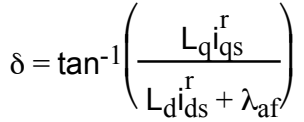

The estimated rotor flux position angle, $\hat{\square}_{\mathrm{r}}$, is found from (6) and shown graphically in Fig. 5.
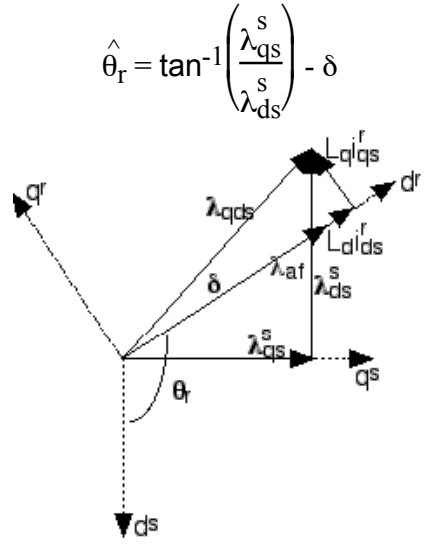

Figure 5: Vector diagram showing flux, current and angles 
This angle estimate is then used in a Luenberger style observer, along with the estimated motor torque, to estimate the rotor speed as shown in Fig. 6 [9]. The flywheel motor control is a particularly good application for this type of observer because the motor torque is due only to acceleration and deceleration of the flywheel inertia; there is no additional load torque and there are essentially no mechanical losses (friction and windage) because the system is operated with magnetic bearings in a vacuum.

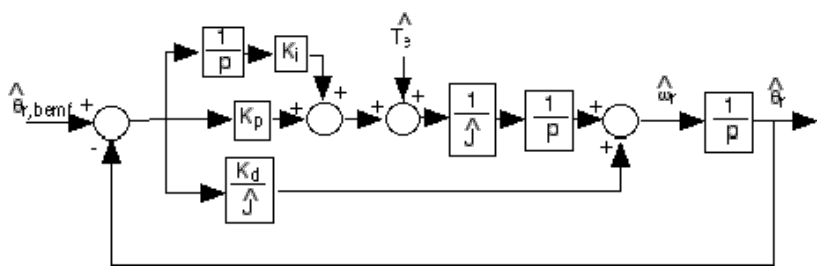

Figure 6: Speed observer.

\section{FLyWheEL CONTROL}

The flywheel system control was designed for three modes of operation based on the requirements of the energy storage sub-system of the Space Station Freedom. The modes of operation are charge, charge reduction and discharge. In charge mode, the solar array produces enough current to both charge the flywheel at its setpoint and provide the required load current. The solar array electronics regulate the DC bus voltage during charge mode. In charge reduction mode, the solar array continues to provide load current but it cannot provide enough current to charge the flywheel at its setpoint. When this occurs, the DC bus voltage regulation function is transferred to the flywheel system. Finally, in discharge mode, the flywheel system provides all of the load current and regulates the DC bus voltage. The features of each mode are given in Table 1 and the corresponding block diagram is shown in Fig. 7.

Table 1: Flywheel system operating mode characteristics

\begin{tabular}{|c|c|c|}
\hline$\underline{\text { Mode }}$ & $\underline{\text { Current }}$ & $\underline{\text { DC Bus Voltage }}$ \\
\hline $\begin{array}{c}\text { Full Sun } \\
\text { "Charge" }\end{array}$ & $\begin{array}{c}\mathrm{I}_{\mathrm{S} / \mathrm{a}}=\mathrm{I}_{\text {load }}+\mathrm{I}_{\text {charge }}^{*} \\
\mathrm{I}_{\text {flywheel }}=\mathrm{I}_{\text {charge }}^{*}\end{array}$ & $\begin{array}{c}\text { Regulated by solar } \\
\text { array system }\end{array}$ \\
\hline $\begin{array}{c}\text { Partial Sun } \\
\text { "Charge } \\
\text { Reduction" }\end{array}$ & $\begin{array}{c}\mathrm{I}_{\text {load }}+\mathrm{I}_{\text {charge }}^{*}>\mathrm{I}_{\mathrm{S} / \mathrm{a}}>0 \\
\mathrm{I}_{\text {flywheel }}<\mathrm{I}_{\text {charge }}^{*}\end{array}$ & $\begin{array}{c}\text { Regulated by } \\
\text { flywheel system }\end{array}$ \\
\hline $\begin{array}{c}\text { Eclipse } \\
\text { "Discharge" }\end{array}$ & $\begin{array}{c}\mathrm{I}_{\text {load }}=-\mathrm{I}_{\text {flywheel }} \\
\mathrm{I}_{\text {flywheel }}<0\end{array}$ & $\begin{array}{c}\text { Regulated by } \\
\text { flywheel system }\end{array}$ \\
\hline
\end{tabular}

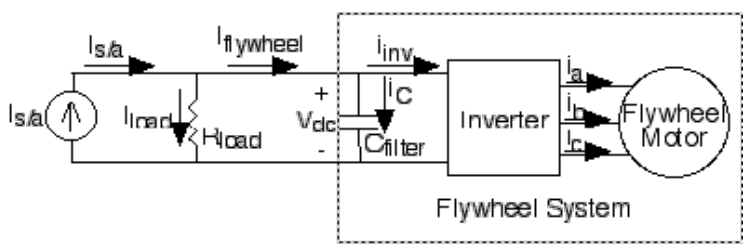

Figure 7: Basic block diagram model of spacecraft power distribution system with flywheel energy storage.
The motor is operated using field oriented control with the rotor reference frame d-axis current command set equal to zero and $\mathrm{q}$-axis current command derived from the flywheel current requirements shown in Table 1. The motor currents are regulated to the commanded values using a synchronous frame PI regulator as shown in Fig. 2.

The relationship between the flywheel current, Iflywheel, and the motor current is based on a steady state power balance between the DC power going into the inverter and the AC power going to the motor. This is shown in (7) where inverter losses are neglected and $\overline{i_{\text {inv }}}$ is the average DC current into the inverter and is equal to $\mathrm{I}_{\text {flywheel }}$ under steady state conditions.

$$
\varlimsup_{\mathrm{inv}} \mathrm{V}_{\mathrm{dc}}=\frac{3}{2}\left(\mathrm{v}_{\mathrm{qs}}^{\mathrm{r}} \mathrm{r}_{\mathrm{qS}}^{\mathrm{r}}+\mathrm{v}_{\mathrm{ds}}^{\mathrm{r}} \mathrm{i}_{\mathrm{ds}}^{\mathrm{r}}\right)
$$

The $\mathrm{q}$-axis voltage, $\mathrm{v}_{\mathrm{q}}^{\mathrm{r}}$, can be expressed as shown in (8) [10].

$$
\mathrm{v}_{\mathrm{qs}}^{\mathrm{r}}=\mathrm{i}_{\mathrm{qS}}^{\mathrm{r}} \mathrm{R}_{\mathrm{s}}+\mathrm{L}_{\mathrm{qs}} \mathrm{pi}_{\mathrm{qs}}^{\mathrm{r}}+\mathrm{i}_{\mathrm{ds}}^{\mathrm{r}} \square_{\mathrm{r}} \mathrm{L}_{\mathrm{ds}}+\square_{\mathrm{r}} \square_{\mathrm{af}}
$$

Noting that $\mathrm{i}_{\mathrm{ds}}^{\mathrm{r}}$ is regulated to zero, neglecting the derivative term due to the assumption of steady state conditions, and combining (7) and (8) gives the following result.

$$
\varlimsup_{\mathrm{inv}} \mathrm{V}_{\mathrm{dc}}=\frac{3}{2}\left(\left(\mathrm{i}_{\mathrm{qS}}^{\mathrm{r}} \mathrm{R}_{\mathrm{s}}+\square_{\mathrm{r}} \square_{\mathrm{af}}\right) \mathrm{i}_{\mathrm{qs}}^{\mathrm{r}}\right)
$$

The voltage drop across the stator resistor, $\mathrm{i}_{\mathrm{qS}}^{\mathrm{r}} \mathrm{R}_{\mathrm{s}}$, is expected to be small compared to the back EMF voltage, $\square_{\mathrm{r}} \square_{\mathrm{a}}$, especially at the high speeds used for the flywheel system. Neglecting $\mathrm{i}_{\mathrm{qs}}^{\mathrm{r}} \mathrm{R}_{\mathrm{s}}$ and rearranging results in the approximate relationship between the motor current and the DC side current as shown.

$$
\mathrm{i}_{\mathrm{qs}}^{\mathrm{r}} \approx \mp \frac{2 \mathrm{~V}_{\mathrm{dc}}}{\mathrm{i}_{\mathrm{inv}}} \frac{\mathrm{r}_{\mathrm{r}} \square_{\mathrm{af}}}{}
$$

This relationship between the motor current and the average inverter current becomes the basis for controlling the flywheel motor in all modes of operation defined by Table 1 . In charge mode, it is used as a feed-forward term in the controller and in charge reduction and discharge modes (when the flywheel system is regulating the DC voltage) it is used as a disturbance decoupling term.

\section{Charge, Charge Reduction and Discharge CONTROL}

In charge mode, the flywheel charges at a constant power, constant DC current rate using the current from the solar array. The charge control algorithm regulates the acceleration of the flywheel motor so that the DC current is maintained at the commanded set point. The block diagram of the charge control algorithm is shown in Fig. 8.

There are two components to the controller: the proportional-integral (PI) and the feed-forward (FF). The feed-forward portion uses the DC charging current command 


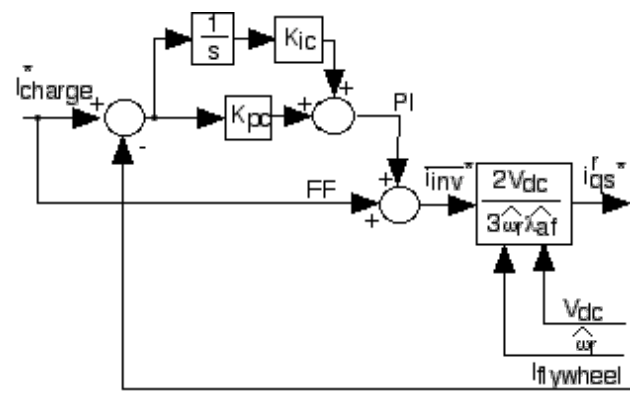

Figure 8: Charge control block diagram.

and converts it into a motor current command using the relationship given in (10), the measured DC bus voltage and the estimated rotor speed from the back EMF estimation algorithm. The PI portion makes up for any inaccuracies in the relationship given in (10) and guarantees zero steady state error. Thus fast, accurate performance is achieved with relatively low gains.

In charge reduction and discharge modes, the flywheel motor must decelerate at the appropriate rate to maintain the DC bus voltage at the commanded value while supplying the necessary current to the loads. The block diagram for this algorithm is shown in Fig. 9.

Again, there are two components to the controller: the PI portion and a disturbance decoupling portion (DD). In the decoupling portion, the DC flywheel current is measured and used as an early indicator to the controller whether there has been an increase or decrease in load. If there is a sudden increase in load, the capacitor will initially maintain the bus voltage and there will be an increase in the DC current, $I_{\text {flywheel }}$, to supply the new load. This increase in $I_{\text {flywheel }}$ is measured and used to calculate the corresponding motor current. Thus the motor responds by decelerating more quickly, even before a drop in the DC bus voltage causes the PI portion to respond.

In the PI portion the measured DC bus voltage is compared to the commanded DC bus voltage and the error signal is inverted. This is because (using the direction references of Fig. 7) the average inverter current needs to become more negative for a decreasing DC bus voltage and less negative for an increasing one. The PI portion makes up for any inaccuracies in the disturbance decoupling portion and maintains the DC bus voltage at the set point.

The two controllers shown in Figs. 8 and 9 are combined to form the overall Charge/Discharge Current/Voltage Regulator (CDCVR) shown in Fig. 10. The system is in

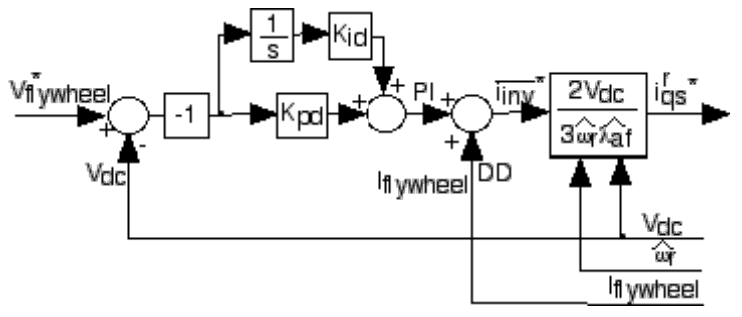

Figure 9: Discharge and charge reduction control block diagram. charge mode (current regulation) when the solar array provides enough current to meet both the load demands and the charging current to the flywheel system. Otherwise, the system is in charge reduction or discharge mode which means that the flywheel system is regulating the DC bus voltage.

The transition from current regulation (Fig. 8) to voltage regulation (Fig. 9) is accomplished in the following manner. The solar array regulates the bus voltage to a set point value about $5 \%$ higher than the flywheel regulation set point as long as the solar array current is sufficient to provide both the load and the charging current, $I_{\text {charge }}^{*}$. Once the solar array current begins to decrease, because the arrays are entering an eclipse period, the DC bus voltage begins to fall and the flywheel current, $I_{\text {flywheel }}$, also decreases. This transition is detected in the controller by comparing the difference between the actual DC bus voltage and the flywheel set point voltage to the "voltage transition constant", VTC, as seen in Fig. 10. Once the bus voltage has dropped far enough so this difference is less than the VTC, the integrator in the PI portion of the controller is reset. This reduces the $i_{\text {inv }}^{*}$ command at point 2 to a value slightly larger than $I_{\text {flywheel }}$. This value is then compared to the charge current set point, $I_{\text {charge }}^{*}$ If it is less than $I_{\text {charge }}^{*}$, which it will be if the solar array is not producing enough current, then the system transitions into charge reduction mode where the DC bus voltage is regulated by the flywheel system.

Similarly, as the system moves from eclipse into sunlight, the solar array will produce more and more current. When the array produces enough current to meet the load demand, the $i$ inv command at point 2 in the controller will become positive. When it exceeds the charge current set point, $I_{\text {charge }}^{*}$, the integrator in the current regulator portion of the controller is reset and the system transitions back into charge mode where the flywheel system regulates the current into the flywheel and the solar array system regulates the DC bus voltage.

The three modes of operation: charge, charge reduction and discharge, were defined based on a battery energy storage

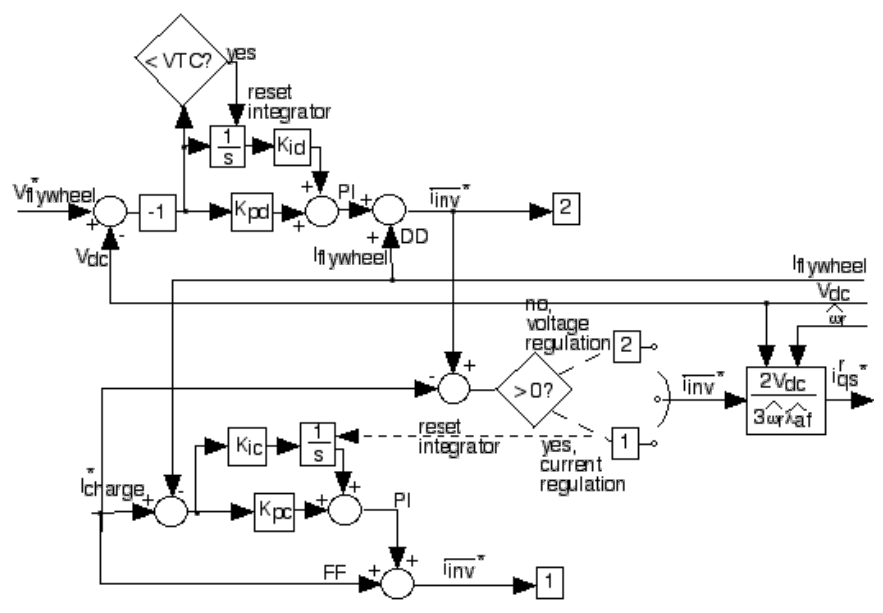

Figure 10: CDCVR control block diagram. 
system. Because the flywheel system is intended to replace batteries, these modes were duplicated in the flywheel system control. However, the flywheel energy storage system is capable of regulating the DC bus voltage both when charging and discharging, obviating the need for multiple modes and the transition between them. Designing the flywheel system control to perform this regulation at all times would result in an overall simpler control strategy, even when considering the necessary provisions to prevent over-speed or overcurrent operation. This is an area for future study.

\section{Simulation Results}

The performance of the CDCVR was simulated using a model that included all of the blocks of Figs. 2 and 10 except the inverter (PWM switching was neglected) and the selfsensing portion (which is only used for start-up). The spacecraft bus was modeled as a capacitance in parallel with a resistive load (Fig. 7), similar to the experimental set up, and the solar array was modeled as a voltage-regulated current source. In charge mode, the DC bus voltage set point is 125 volts and in discharge mode, the set point is 120 volts. These values are representative of a future spacecraft system. There is $4800 \square \mathrm{F}$ of capacitance on the DC bus.

Figures 11-14 show the simulation results. The system is initially in the charge mode at 50,000 rpm and charging at a constant current of 1.5 amps. At time $t=3$ seconds, the available current from the source is reduced and the DC bus voltage begins to drop. The system goes into charge reduction mode and the flywheel begins to regulate the DC bus voltage to 120 volts. From time $\mathrm{t}=3$ to $\mathrm{t}=3.5$, the source is still providing enough current to meet the load and to charge the flywheel system, although at a slower and slower rate. At time $\mathrm{t}=3.5$, the source no longer provides enough additional current to charge the flywheel and at $\mathrm{t}=4$, the source current goes to zero and the flywheel system provides all of the current for the load. At $\mathrm{t}=7$, a step change in load occurs. It can be seen that no transient occurs on the DC bus voltage. This is due to the action of the disturbance decoupling portion of the controller as shown in Fig. 9. The controller uses the measured flywheel current to increase the motor current command according to (10) as soon as the load is added, before the bus voltage drops. Finally, at $t=9$, the available current from the source is increased and the system moves from discharge back into charge mode.

\section{EXPERIMENTAL RESULTS}

The experimental set-up was similar to the block diagram shown in Fig. 7. The "solar array" was a DC power supply with current limiting capability, set to regulate the bus to 125 volts. The "load resistor" consisted of multiple parallel resistors that could be switched in and out from a minimum load of $300 \square$ to a total maximum of $17 \square$. The current was measured at the three points corresponding to $\mathrm{I}_{\mathrm{S} / \mathrm{a}}$, $\mathrm{I}_{\text {flywheel }}$ and $\mathrm{I}_{\text {load }}$ in Fig. 7. The DC bus voltage and two motor phase currents were also measured and fed back to the controller.

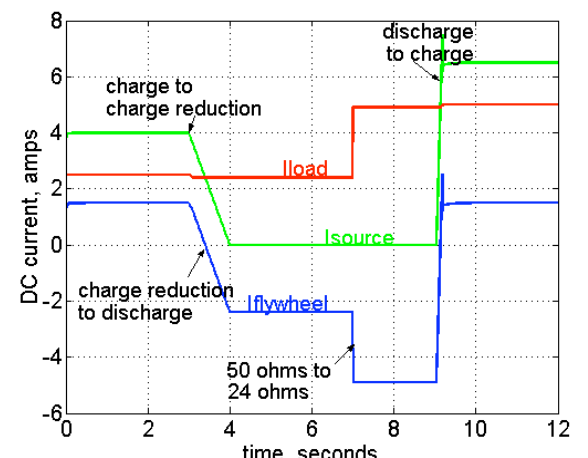

Figure 11: Simulation results of DC currents during mode transitions and step change in load

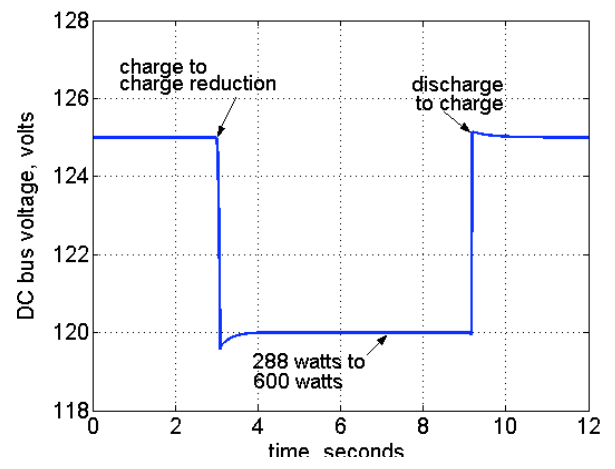

Figure 12: Simulation results of DC bus voltage during mode transitions and step change in load.

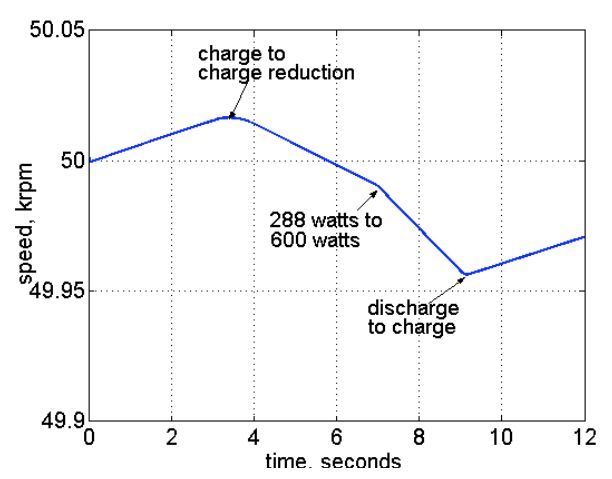

Figure 13: Simulation results of flywheel rotor speed during mode transitions and step change in load.

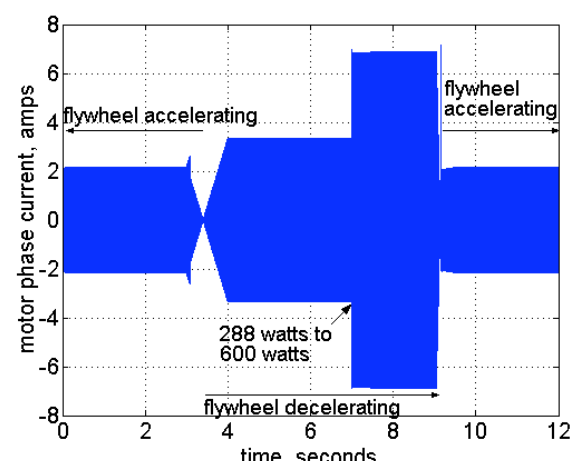

Figure 14: Simulation results of motor phase currents during mode transitions and step change in load 
The control algorithm was written in Simulink ${ }^{1}$ and executed using a dSpace ${ }^{1}$ digital controller. The dSpace ${ }^{1}$ data acquisition system was used to capture the data and Matlab ${ }^{1}$ was used to create the plots. Figures $15-18$ show the results as the flywheel operates near $56,000 \mathrm{rpm}$ in both charge and discharge modes of operation.

The first transition occurs at $\mathrm{t}=0$ seconds when the system transitions from charge mode to discharge mode. Figure 15 shows the supply current dropping to zero and the flywheel current becoming negative, thus indicating a discharge mode of operation. The load current drops slightly because the DC bus voltage is reduced from 125 volts during charge mode to 120 volts during discharge. Then at $\mathrm{t}=5$ seconds, the maximum load is added to the system. The load current rises to the new value and the flywheel current increases to meet the new demand.

The DC bus voltage is shown in Fig. 16. The transition from charge to discharge is seen to be quite good with very little undershoot. However, there is a disturbance on the bus voltage when the additional load is added. This was not anticipated in the original derivation of the control and the modification necessary to correct for it is discussed below.

Figure 17 shows the rotor speed accelerating prior to $t=0$ and decelerating afterwards, indicating that the flywheel system is discharging after $\mathrm{t}=0$. At $\mathrm{t}=5$ seconds, the rate of deceleration increases due to the additional load.

Finally, Fig. 18 shows the motor phase current envelope. The magnitude decreases at $\mathrm{t}=0$ because the current necessary to meet the load demand is less than the charging current command as seen in Fig. 15. In other words, at $t=0^{+}$the flywheel is decelerating less rapidly than it had been accelerating at $\mathrm{t}=0^{-}$. At $\mathrm{t}=5$, the additional load causes a faster deceleration and a larger motor phase current.

\section{A. Control Modification}

The fast response of the flywheel system control is based on the principles of command feedforward and disturbance decoupling as explained in Section IV. This, in turn, is based on the relationship between the DC current, $\overline{i_{\text {inv }}}$, and the motor current, $\mathrm{i}_{\mathrm{qs}}^{\mathrm{r}}$, as developed in equations (7) through (10). However, (7) assumes that there are no inverter losses and moving from (9) to (10), repeated here for convenience, neglects the voltage drop across the motor resistance.

$$
\begin{gathered}
\overline{\mathrm{inv}}_{\mathrm{inv}} \mathrm{V}_{\mathrm{dc}}=\frac{3}{2}\left(\left(\mathrm{i}_{\mathrm{qs}}^{\mathrm{r}} \mathrm{R}_{\mathrm{s}}+\square_{\mathrm{r}} \square_{\mathrm{af}}\right) \mathrm{i}_{\mathrm{qs}}^{\mathrm{r}}\right) \\
\mathrm{i}_{\mathrm{qs}}^{\mathrm{r}} \approx \overline{i_{\text {inv }}} \frac{2 \mathrm{~V}_{\mathrm{dc}}}{3 \square_{\mathrm{r}} \square_{\mathrm{af}}}
\end{gathered}
$$

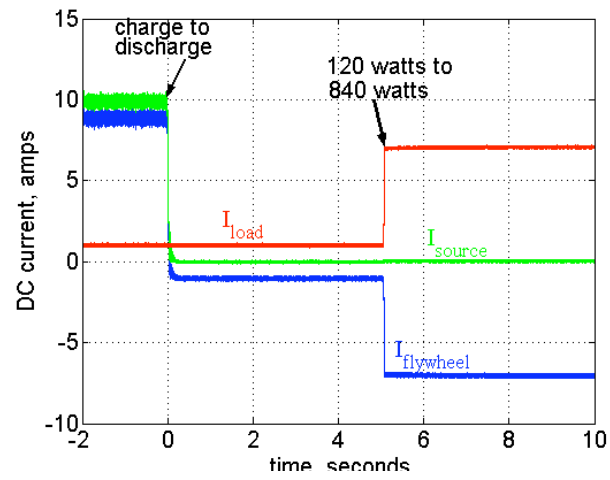

Figure 15: DC current during charge to discharge operation with a step change in load.

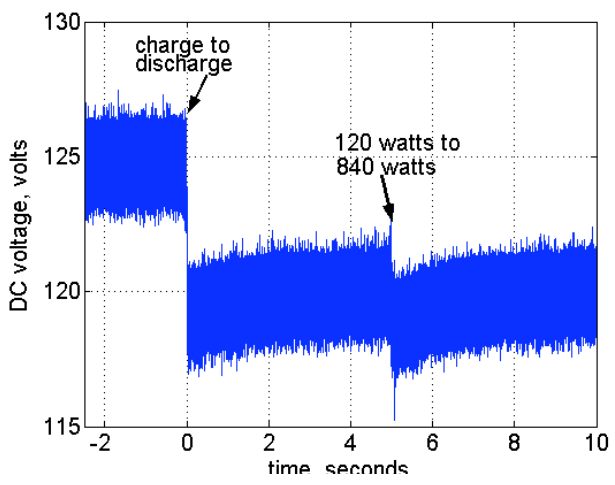

Figure 16: DC bus voltage.

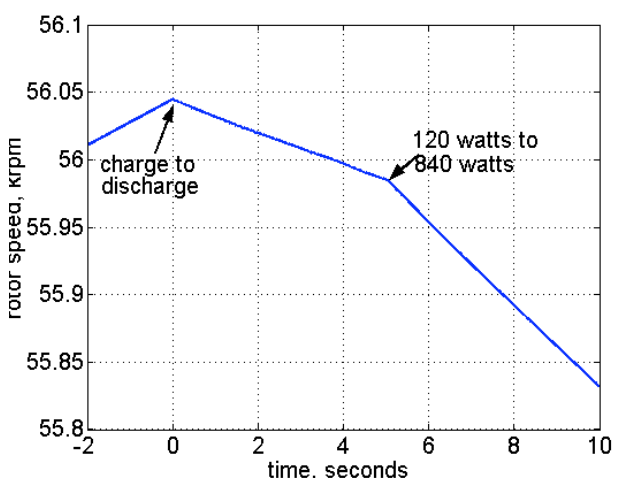

Figure 17: Estimated rotor speed.

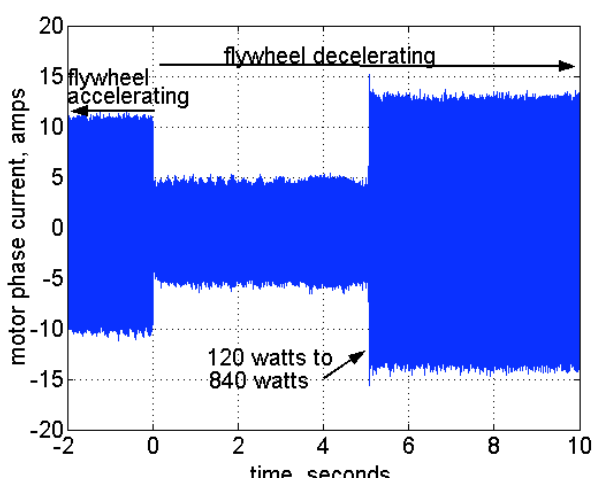

Figure 18: Motor phase current. 
In fact, there are inverter losses and they need to be considered in order to improve the control. One way to model the losses is to include an additional resistive term, $\mathrm{R}_{\mathrm{inv}}$, on the AC side of the power balance equation given in (9) as shown in (11). This effectively makes the assumption that the losses in the inverter are linearly proportional to magnitude of the motor phase current, $\mathrm{i}_{\mathrm{qs}}^{\mathrm{r}}$.

$$
\overline{\mathrm{i}_{\mathrm{inv}}} \mathrm{V}_{\mathrm{dc}}=\frac{3}{2}\left(\left(\mathrm{i}_{\mathrm{qs}}^{\mathrm{r}} \mathrm{R}_{\mathrm{s}}+\mathrm{i}_{\mathrm{qs}}^{\mathrm{r}} \mathrm{R}_{\mathrm{inv}}+\square_{\mathrm{r}} \square_{\mathrm{af}}\right) \mathrm{i}_{\mathrm{qs}}^{\mathrm{r}}\right)
$$

The addition of the inverter loss term, however, makes the relationship between the DC side current, $\overline{i_{\text {inv }}}$, and the $\mathrm{AC}$ side current, $\mathrm{i}_{\mathrm{q}}^{\mathrm{r}}$, non-linear. Solving for the motor control current, $\mathrm{i}_{\mathrm{qs}}^{\mathrm{r}}$, now involves linearizing the quadratic equation given in (12) about an operating point where $\mathrm{R}$ is the sum of the stator resistance, $R_{s}$, and the effective inverter resistance, $\mathrm{R}_{\text {inv }}$.

$$
0=\frac{3}{2}\left(\mathrm{i}_{\mathrm{qS}}^{\mathrm{r}}\right)^{2} \mathrm{R}+\frac{3}{2} \mathrm{i}_{\mathrm{qS}}^{\mathrm{r}} \square \mathrm{r} \square_{\mathrm{af}}-\varlimsup_{\mathrm{inv}} \mathrm{V}_{\mathrm{dc}}
$$

Linearizing about the measured value of current, $\mathrm{i}_{\mathrm{qs}}^{\mathrm{rM}}$, gives the relationship between the DC side current and the motor control current as shown in (13). This equation could be used in the controller (Fig. 10) to determine the commanded motor current, $\mathrm{i}_{\mathrm{qs}}^{\mathrm{r}}$, given the desired DC current, $\overline{\mathrm{inv}}^{*}$.

$$
\mathrm{i}_{\mathrm{qs}}^{\mathrm{r} *} \approx \frac{\varlimsup_{\mathrm{inv}}^{*} \mathrm{~V}_{\mathrm{dc}}+\frac{3}{2}\left(\mathrm{i}_{\mathrm{qs}}^{\mathrm{rM}}\right)^{2} \mathrm{R}}{3 \mathrm{i}_{\mathrm{qs}}^{\mathrm{rM}} \mathrm{R}+\frac{3}{2} \square_{\mathrm{r}} \square_{\mathrm{af}}}
$$

However, another way to solve for the motor control current that is easier and more intuitive to implement is to return to equation (11) and consider the measured current, $\mathrm{i}_{\mathrm{qs}}^{\mathrm{rM}}$, separately from the commanded motor control current, $\mathrm{i}_{\mathrm{qs}}^{\mathrm{r}^{*}}$. This is shown in (14).

$$
\overline{\mathrm{i}_{\mathrm{inv}}} \mathrm{V}_{\mathrm{dc}} \approx \frac{3}{2}\left(\left(\mathrm{i}_{\mathrm{qs}}^{\mathrm{rM}} \mathrm{R}+\square_{\mathrm{r}} \square_{\mathrm{af}}\right) \mathrm{i}_{\mathrm{qs}}^{\mathrm{r}^{*}}\right)
$$

Using (14), the relationship between the commanded motor control current and the desired DC current is given in (15). (Equations (13) and (15) are almost equivalent as shown in the Appendix).

$$
\mathrm{i}_{\mathrm{qs}}^{\mathrm{r}} \approx \overline{\mathrm{inv}}_{\mathrm{inv}}^{*} \frac{2 \mathrm{~V}_{\mathrm{dc}}}{3\left(\mathrm{i}_{\mathrm{qS}}^{\mathrm{rM}} \mathrm{R}+\square_{\mathrm{r}} \square_{\mathrm{af}}\right)}
$$

The results using (15) instead of (10) in the controller are shown in Figs. 19 through 22. It can be seen that the voltage disturbance during the load transient, as shown in Fig. 20, is eliminated. The other results remain the same.

\section{B. Complete Cycle Results}

Figures 23 through 26 show the results using the modified controller through all of the modes: charge to charge

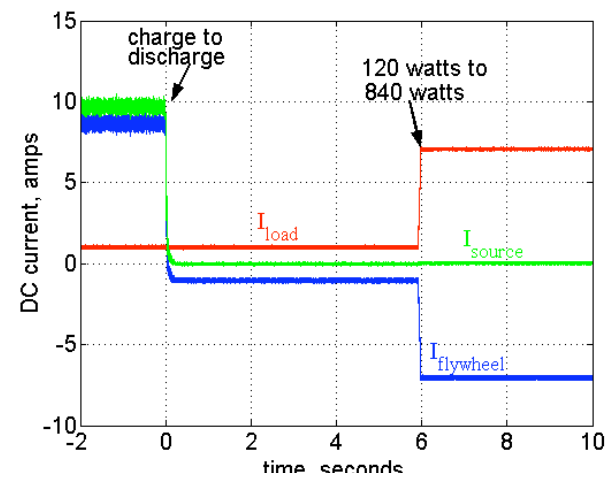

Figure 19: DC current during charge to discharge operation with a step change in load using the modified controller.

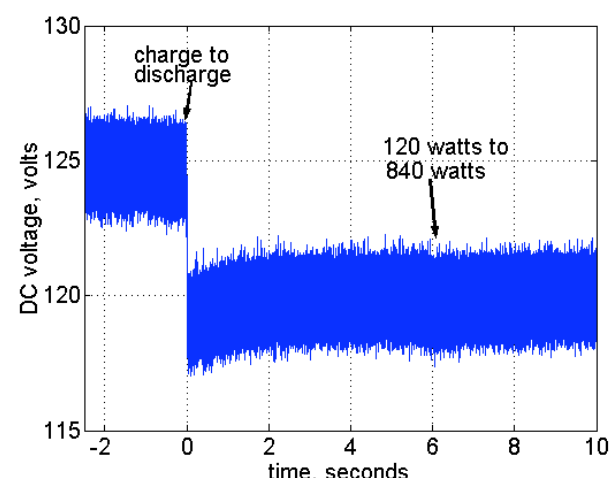

Figure 20: DC bus voltage using the modified controller.

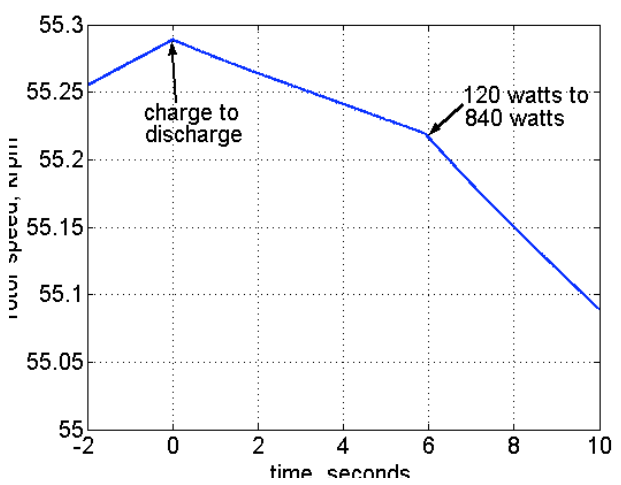

Figure 21: Estimated rotor speed using the modified controller.

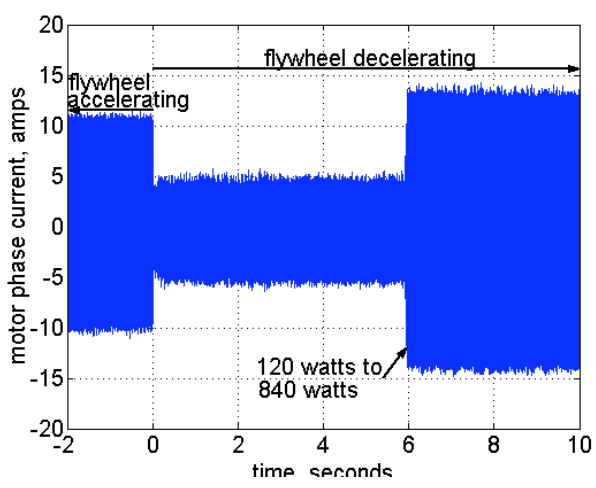

Figure 22: Motor phase current using the modified controller. 
reduction to discharge and then back to charge. Additionally, two transients are shown: a change in the charging current command and a step change in load.

Figure 23 shows the DC currents. At time $\mathrm{t}=0$ there is a step change in the charging current command from $2.5 \mathrm{amps}$ to $10 \mathrm{amps}$ that the flywheel current tracks with a brief overshoot. The increase in charging rate can be seen in the speed plot of Fig. 25 where the acceleration of the flywheel increases at $\mathrm{t}=0$. At $\mathrm{t}=4.9$ seconds, the current limit on the DC supply is reduced to $2.5 \mathrm{amps}$ and the flywheel system moves into charge reduction mode. This can be seen in Fig. 24 when the DC bus voltage drops from 125 volts to 120 volts. The source continues to supply the load current from $\mathrm{t}=4.9$ to $\mathrm{t}=7.6$ seconds and the flywheel current is still slightly positive. However, in spite of the positive DC flywheel current, Fig. 25 shows a slow deceleration of the rotor speed. This is due to the losses on the AC side of the system, including the inverter. During this time, the supply and the flywheel are jointly supplying the load and the losses.

At $t=7.6$, the supply current limit is set to zero and the system moves into discharge mode. There is no change in the bus voltage and the flywheel current in Fig. 23 becomes negative, indicating that it is now supplying the load in addition to the losses. The rotor decelerates more quickly as shown in Fig. 25. At $t=12$ seconds, the load is increased from 280 to 850 watts. The flywheel current becomes more negative to supply the additional load and the rotor decelerates even more quickly. As seen earlier, the modification in the controller eliminates the disturbance in the DC bus voltage during the load step.

Finally, at $\mathrm{t}=16$ seconds, the source is turned back on and the system moves back into charge mode. The flywheel current returns to the charging command of $10 \mathrm{amps}$ and the source provides this current plus the additional load current now required. The bus voltage returns to 125 volts and the flywheel speed increases.

Figure 26 shows the phase current envelope during the transitions. Although the scale of Fig. 26 doesn't show it, at $\mathrm{t}=4.9$ and $\mathrm{t}=12$ the phase current transitions through zero as the flywheel power reverses direction.

\section{CONCLUSIONS AND FUTURE WORK}

This paper has presented a new algorithm for regulating the charge and discharge modes of a high speed $(60,000 \mathrm{rpm})$ flywheel energy storage system using a sensorless field orientation control algorithm to provide the inner loop torque control. The algorithm mimics the operational modes presently found in battery systems and would allow the flywheel system to replace batteries on future spacecraft. Experimental and simulation results show the successful control of the flywheel system permanent magnet motor at full speed in all modes of operation. Additionally, a modification was added to the original controller to improve the DC bus voltage regulation during step changes in load.

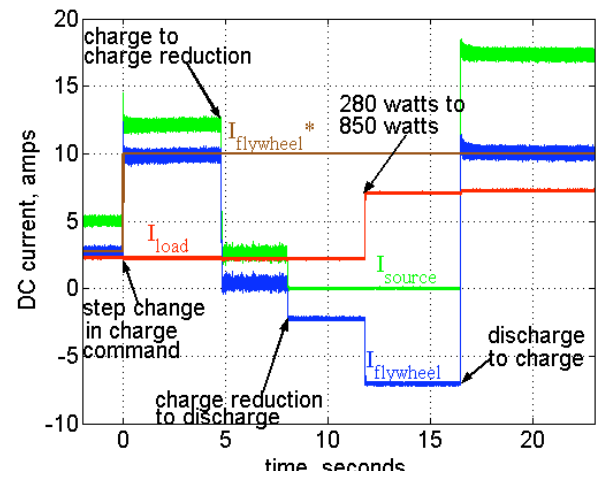

Figure 23: DC current in multiple modes using the modified controller.

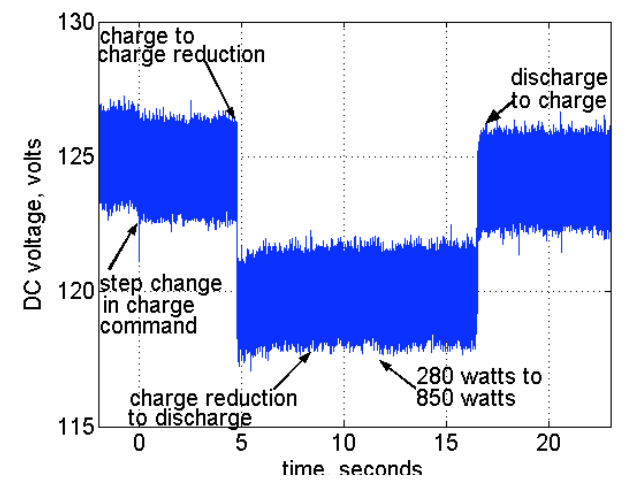

Figure 24: DC voltage in multiple modes using the modified controller.

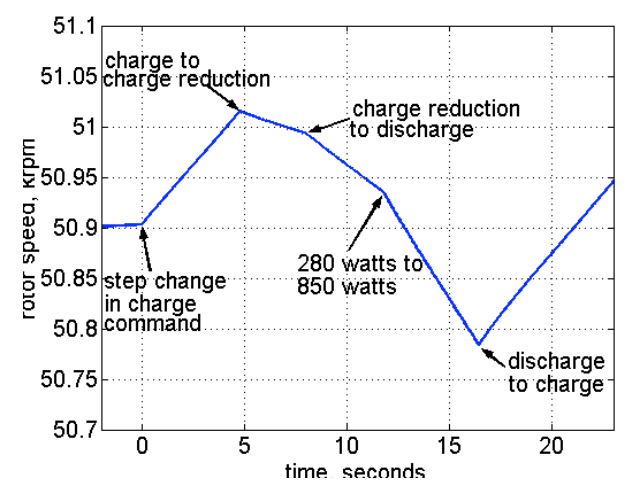

Figure 25: Rotor speed in multiple modes using the modified controller.

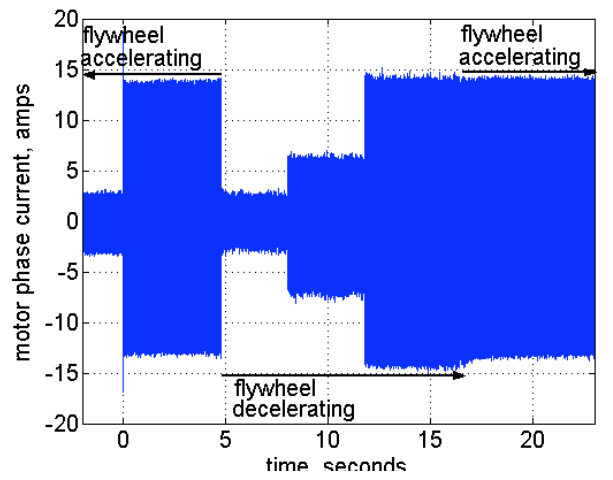

Figure 26: Phase Current in multiple modes using the modified controller. 
Another application of flywheel technology is to use flywheels to combine the energy storage and the attitude control functions on a spacecraft. The NASA Glenn Research Center has recently demonstrated a single axis of attitude control combined with energy storage using two flywheel systems [11]. A minimum of four flywheels would be needed to provide three axes of attitude control plus energy storage on a satellite. This is the direction of future research at the NASA Glenn Research Center.

\section{REFERENCES}

[1] B. H. Kenny, P. E. Kascak, "Sensorless Control of Permanent Magnet Machine for NASA Flywheel Technology Development", $37^{\text {th }}$ Annual IECEC, Washington DC., July 28-August 2, 2002. NASA TM 2002211726.

[2] P. Jansen and R. D. Lorenz, "Transducerless Position and Velocity Estimation in Induction and Salient AC Machines", IEEE Transactions on Industry Applications, Vol. 31, No. 2, March/April 1995 pp. 240247.

[3] R. Wu, and G. Slemon, "A Permanent Magnet Motor Drive Without a Shaft Sensor", IEEE Transactions on Industry Applications, Vol. 27, No. 5, September/October 1991, pp. 1005-1011.

[4] N. Patel,, T. O'Meara, J. Nagashima, R. Lorenz, "Encoderless IPM Traction Drive for EV/HEV's", Conference Record of the 2001 IEEE Industry Applications Conference, Chicago, Il, October, 2001.

[5] P.E. Kascak, B. H. Kenny, T. P. Dever, W. Santiago, R. H. Jansen, "International Space Station Bus Regulation with NASA Glenn Research Center Flywheel Energy Storage System Development Unit", $36^{\text {th }}$ Annual IECEC, Savannah, Ga., July 29-August 2, 2001. NASA TM 2001-211138.

[6] B. H. Kenny, P. E. Kascak, "DC Bus Regulation with a Flywheel Energy Storage System", Proceedings of the Society of Automotive Engineers Power Systems Conference, October 29-31, 2002, Coral Springs, Fl., CD ROM. NASA TM 2002-211897.

[7] N. Matsui, "Sensorless PM Brushless DC Motor Drives", IEEE Transactions on Industrial Electronics, Vol. 43, No. 2, April, 1996, pp. 300-308.

[8] B. H. Kenny, et. al., "Advanced motor control test facility for NASA GRC flywheel energy storage system development unit", Proceedings $36^{\text {th }}$ Intersociety Energy Conversion Engineering Conference, July 29Aug. 2, 2001, CD ROM. NASA TM 2001-210986.

[9] R. D. Lorenz, K.W. Van Patten, "High-resolution velocity estimation for all-digital, AC servo drives" IEEE Transactions on Industry Applications, Vol 27, No. 4, July/August 1991, pp. 701-705.

[10] R. Krishnan, Permanent magnet synchronous and brushless DC motor drives: theory, operation, performance, modeling, simulation, analysis and design, Virginia Polytechnical Institute, Blacksburg, Va., 1999.

[11] B.H. Kenny, R. Jansen, P.E. Kascak, T. Dever, W. Santiago, "Demonstration of Single Axis Combined Attitude Control and Energy Storage Using Two Flywheels", Proceedings of the 2004 Aerospace Conference, March 6-13, 2004, CD ROM. NASA TM 2004-212935.

\section{APPENDIX}

The linearization of (12) about the operating point $\mathrm{i}_{\mathrm{qS}}^{\mathrm{rM}}$ is shown below.

$$
0=\frac{3}{2}\left(\mathrm{i}_{\mathrm{qS}}^{\mathrm{r}}\right)^{2} \mathrm{R}+\frac{3}{2} \mathrm{i}_{\mathrm{qS}}^{\mathrm{r}} \square_{\mathrm{r}} \square_{\mathrm{af}}-\mathrm{i}_{\mathrm{inv}} \mathrm{V}_{\mathrm{dc}}
$$

Rearranging terms gives (16).

$$
\mathrm{i}_{\text {inv }} \mathrm{V}_{\mathrm{dc}}=\frac{3}{2}\left(\mathrm{i}_{\mathrm{qs}}^{\mathrm{r}}\right)^{2} \mathrm{R}+\frac{3}{2} \mathrm{i}_{\mathrm{qs}}^{\mathrm{r}} \square_{\mathrm{r}} \square_{\mathrm{af}}
$$

$$
\begin{gathered}
\frac{\square \mathrm{i}_{\overline{\mathrm{inv}}}}{\square \mathrm{i}_{\mathrm{qs}}^{\mathrm{r}}} \mathrm{V}_{\mathrm{dc}} \approx 3 \mathrm{i}_{\mathrm{qs}}^{\mathrm{rM}} \mathrm{R}+\frac{3}{2} \square_{\mathrm{r}} \square_{\mathrm{af}} \\
\square \mathrm{i}_{\overline{\mathrm{inv}}}=\mathrm{i}_{\overline{\mathrm{inv}}}^{*}-\mathrm{i}_{\overline{\mathrm{inv}}} \\
\square \mathrm{i}_{\mathrm{qs}}^{\mathrm{r}}=\mathrm{i}_{\mathrm{qs}}^{\mathrm{r} *}-\mathrm{i}_{\mathrm{qs}}^{\mathrm{rM}}
\end{gathered}
$$

Combining (16), (17), (18) and (19) and rearranging leads to the following.

$$
\begin{aligned}
& i_{\text {inv }}^{*} \mathrm{~V}_{\mathrm{dc}} \approx \frac{3}{2}\left(\mathrm{i}_{\mathrm{qs}}^{\mathrm{rM}}\right)^{2} \mathrm{R}+\frac{3}{2} \mathrm{i}_{\mathrm{qs}}^{\mathrm{rM}} \square_{\mathrm{r}} \square_{\mathrm{af}}+\mathrm{i}_{\mathrm{qs}}^{\mathrm{r} *}\left(3 \mathrm{i}_{\mathrm{qs}}^{\mathrm{rM}} \mathrm{R}+\frac{3}{2} \square_{\mathrm{r}} \square_{\mathrm{af}}\right) \\
& -\mathrm{i}_{\mathrm{qS}}^{\mathrm{rM}}\left(3 \mathrm{i}_{\mathrm{qS}}^{\mathrm{rM}} \mathrm{R}+\frac{3}{2} \square_{\mathrm{r}} \square_{\mathrm{af}}\right) \\
& \mathrm{i}_{\mathrm{inv}}^{*} \mathrm{~V}_{\mathrm{dc}} \approx-\frac{3}{2}\left(\mathrm{i}_{\mathrm{qs}}^{\mathrm{rM}}\right)^{2} \mathrm{R}+3 \mathrm{i}_{\mathrm{qs}}^{\mathrm{r}^{*}} \mathrm{i}_{\mathrm{qs}}^{\mathrm{rM}} \mathrm{R}+\frac{3}{2} \mathrm{i}_{\mathrm{qs}}^{\mathrm{r} *} \square_{\mathrm{r}} \square_{\mathrm{af}}
\end{aligned}
$$

Solving (21) for $\mathrm{i}_{\mathrm{qs}}^{\mathrm{r*}}$ leads directly to (13).

$$
\mathrm{i}_{\mathrm{qs}}^{\mathrm{r} *} \approx \frac{\overline{\mathrm{inv}}^{*} \mathrm{~V}_{\mathrm{dc}}+\frac{3}{2}\left(\mathrm{i}_{\mathrm{qs}}^{\mathrm{rM}}\right)^{2} \mathrm{R}}{3 \mathrm{i}_{\mathrm{qs}}^{\mathrm{rM}} \mathrm{R}+\frac{3}{2} \square_{\mathrm{r}} \square_{\mathrm{af}}}
$$

However, if $\mathrm{i}_{\mathrm{qs}}^{\mathrm{r}}$ is substituted for one of the $\mathrm{i}_{\mathrm{qs}}^{\mathrm{rM}}$ terms in (21) as shown in (22), then (15) can be found from (23). This is a reasonable substitution because the current regulator bandwidth is on the order of $1-2 \mathrm{kHz}$ and $\mathrm{i}_{\mathrm{qs}}^{\mathrm{rM}}$ closely follows $\mathrm{i}_{\mathrm{qs}}^{\mathrm{r}^{*}}$.

$$
\begin{aligned}
& \overline{\mathrm{inv}}^{*} \mathrm{~V}_{\mathrm{dc}} \approx-\frac{3}{2}\left(\mathrm{i}_{\mathrm{qs}}^{\mathrm{rM}} \mathrm{i}_{\mathrm{qs}}^{\mathrm{r}^{*}}\right) \mathrm{R}+3 \mathrm{i}_{\mathrm{qs}}^{\mathrm{r}^{*}} \mathrm{i}_{\mathrm{qs}}^{\mathrm{rM}} \mathrm{R}+\frac{3}{2} \mathrm{i}_{\mathrm{qs}}^{\mathrm{r}^{*}} \square_{\mathrm{r}} \square_{\mathrm{af}} \\
& \mathrm{i}_{\text {inv }}^{*} \mathrm{~V}_{\mathrm{dc}} \approx \mathrm{i}_{\mathrm{qs}}^{\mathrm{r} *}\left[\frac{3}{2} \mathrm{i}_{\mathrm{qs}}^{\mathrm{rM}} \mathrm{R}+\frac{3}{2} \square_{\mathrm{r}} \square_{\mathrm{af}}\right. \\
& \mathrm{i}_{\mathrm{qs}}^{\mathrm{r}} \approx \overline{\mathrm{i}}_{\mathrm{inv}}^{*} \frac{2 \mathrm{~V}_{\mathrm{dc}}}{3\left(\mathrm{i}_{\mathrm{qs}}^{\mathrm{rM}} \mathrm{R}+\square_{\mathrm{r}} \square_{\mathrm{af}}\right)}
\end{aligned}
$$




\begin{tabular}{|c|c|c|c|}
\hline \multicolumn{3}{|c|}{ REPORT DOCUMENTATION PAGE } & $\begin{array}{l}\text { Form Approved } \\
\text { OMB No. 0704-0188 }\end{array}$ \\
\hline \multicolumn{4}{|c|}{$\begin{array}{l}\text { Public reporting burden for this collection of information is estimated to average } 1 \text { hour per response, including the time for reviewing instructions, searching existing data sources, } \\
\text { gathering and maintaining the data needed, and completing and reviewing the collection of information. Send comments regarding this burden estimate or any other aspect of this } \\
\text { collection of information, including suggestions for reducing this burden, to Washington Headquarters Services, Directorate for Information Operations and Reports, } 1215 \text { Jefferson } \\
\text { Davis Highway, Suite 1204, Arlington, VA 22202-4302, and to the Office of Management and Budget, Paperwork Reduction Project (0704-0188), Washington, DC 20503. }\end{array}$} \\
\hline 1. AGENCY USE ONLY (Leave blank) & \begin{tabular}{|l|} 
2. REPORT DATE \\
November 2004
\end{tabular} & 3. $\mathrm{F}$ & $\begin{array}{l}\text { ID DATES COVERED } \\
\text { echnical Memorandum }\end{array}$ \\
\hline \multicolumn{3}{|c|}{$\begin{array}{l}\text { 4. TITLE AND SUBTITLE } \\
\text { Control of a High Speed Flywheel System for Energy Storage } \\
\text { in Space Applications }\end{array}$} & \multirow{2}{*}{$\begin{array}{l}\text { 5. FUNDING NUMBERS } \\
\text { WBS-22-319-20-M1 }\end{array}$} \\
\hline \multicolumn{3}{|c|}{$\begin{array}{l}\text { 6. AUTHOR(S) } \\
\text { Barbara H. Kenny, Peter E. Kascak, Ralph Jansen, Timothy Dever, } \\
\text { and Walter Santiago }\end{array}$} & \\
\hline \multicolumn{3}{|c|}{ 9. SPONSORING/MONITORING AGENCY NAME(S) AND ADDRESS(ES) } & $\begin{array}{l}\text { 10. SPONSORING/MONITORING } \\
\text { AGENCY REPORT NUMBER }\end{array}$ \\
\hline
\end{tabular}

Barbara H. Kenny and Walter Santiago, NASA Glenn Research Center; Peter E. Kascak and Ralph Jansen, University of Toledo, Toledo, Ohio 43606; and Timothy Dever, QSS Group, Inc., Cleveland, Ohio 44135. Responsible person, Barbara H. Kenny, organization code 5450, 216-433-6289.

12a. DISTRIBUTION/AVAILABILITY STATEMENT

12b. DISTRIBUTION CODE

Unclassified - Unlimited

Subject Categories: 44 and 20

Distribution: Nonstandard

Available electronically at http://gltrs.grc.nasa.gov

This publication is available from the NASA Center for AeroSpace Information, 301-621-0390.

13. ABSTRACT (Maximum 200 words)

A novel control algorithm for the charge and discharge modes of operation of a flywheel energy storage system for space applications is presented. The motor control portion of the algorithm uses sensorless field oriented control with position and speed estimates determined from a signal injection technique at low speeds and a back EMF technique at higher speeds. The charge and discharge portion of the algorithm use command feed-forward and disturbance decoupling, respectively, to achieve fast response with low gains. Simulation and experimental results are presented demonstrating the successful operation of the flywheel control up to the rated speed of $60,000 \mathrm{rpm}$.

\begin{tabular}{|c|c|c|c|}
\hline \multicolumn{3}{|l|}{ 14. SUBJECT TERMS } & 15. NUMBER OF PAGES \\
\hline \multicolumn{3}{|c|}{$\begin{array}{l}\text { Flywheel energy storage; Permanent magnet motor; Charge control; } \\
\text { Discharge control; Bus regulation }\end{array}$} & \\
\hline Unclassified & Unclassified & Unclassified & \\
\hline \multicolumn{3}{|l|}{ NSN 7540-01-280-5500 } & ndard Form 298 (Rev. 2-89) \\
\hline
\end{tabular}



